\title{
The Chairman's Annual Report for the Year 1982-83
}

The Society organized the seventeenth annual course of lectures of Byelorussian history, literature and culture during the academic year 1982-83. The course included the following lectures:

4 November 'War and Peace in the Prose of Vasil Bykaŭ', Professor A. McMillin

3 February 'The Bohohtasnik', G. Picarda

3 March 'The 16th-Century Byelorussian Town', Dr A. French

14 April 'Byelorussian Prayer-Books for Laymen (16th-17th centuries)', Very Revd. A. Nadson

12 May 'New Publications in Byelorussian Studies in the BSSR', Dr S. Akiner

23 June 'Hunting the Snark - Byelorussian-Latin Style', J. Dingley

Attendances at the lectures varied from 13 to 27 . The Society was privileged to have as distinguished guest at the first of these lectures Dr Adam Maldzis, head of the Byelorussian Literature section of the BSSR Academy of Sciences. On 18 November, Dr Maldzis gave a special talk, attended by several members and friends of the Society, entitled 'The present state of literary research in the BSSR'. Dr Maldzis' two-month working visit to the Francis Skaryna Library has further strengthened the desire of the Society for scholarly contacts with Soviet Byelorussia.

Two close friends of the Society died during the year, Fr Felix Žurnia in December 1982 and Mr Paul Navaro in May 1983. Fr Žurnia was a gentle, unassuming person whose absence is keenly felt. Paul Navaro was one of the founding members of the Society and for many years a valuable member of the Council. I am sure that all members will join me in sending condolences to his family, and in ensuring the continued well-being of the Society as the best way of honouring his memory.

The Council of the Society met on 21 October 1982 and 14 June 1983. It was agreed at the first of these meetings that the idea of members actually paying a membership subscription should be reactivated; dues were fixed at $£ 5$ per annum for ordinary members, £3 per annum for students and pensioners and $£ 50$ for life membership. Three new members have joined the Society: Mr J. Anderson, Ms Nina Taylor (both proposed by the Chairman and seconded by the Secretary) and Mr A. Zdankovič (proposed by Mr J. Michaluk and seconded by the Chairman). There are to date two life members of the Society: the Very Revd A. Nadson and Mr P. Asipowich. I reported to the second meeting of 
the Council that the Vice-Presidents (The Marchioness of Dufferin and Ava, the Lord Egremont, the Hon. John Jolliffe and Professor A. McMillin) have expressed a continuing interest in the work of the Society.

On 9 October 1982 the Society, jointly with the Francis Skaryna Library and the Association of Byelorussians in Great Britain, organized a very successful one-day seminar on Janka Kupała and Jakub Kołas, with papers from Dr A. Barščeǔski (Warsaw), Mr A. Adamovič (New York), Mr B. Zaboraŭ (Paris), Fr A. Nadson (London) and Professor A. McMillin (Liverpool). The papers were published in Vol.V, No.2 of the Journal of Byelorussian Studies. In the evening Ms Vera Rich organized an excellent poetry-reading session; the Society is very much indebted to her and her team of readers for bringing our celebration of Byelorussia's greatest poets to such a splendid conclusion. Plans are well in hand for the next one-day seminar, to be held on Saturday 15 October 1983 to mark the centenary of the birth of Vacłaŭ Lastoŭski. With promises of papers from Poland, Spain and the USA, as well as this country, the occasion promises to be a most interesting one. I am also pleased to be able to report that the Society has been awarded $£ 800$ by the Ford Foundation towards the costs of holding the seminar.

During the year the Society published a book entitled The Images Swarm Free, a bilingual selection of poetry by Maksim Bahdanovič, Aleś Harun and Źmitrok Biadula, with the original Byelorussian texts, translations by Vera Rich and an introduction by Prof. A. McMillin. Publication of this book was made possible by a grant from the Byelorussian Charitable Trust.

Thanks are due to the Hon. Treasurer, Mr Paul Asipowich, for his hard work in maintaining the Society's accounts in good order. Once again I draw members' attention to the continuing genorosity of the Byelorussian Charitable Trust; it is quite evident that the Society could not exist without the Trust's invaluable assistance. I should also like to thank Mr J. Michaluk for acting so efficiently as distributor of the Society's publications. Mrs Helen Michaluk and Mrs Joan Dziejko continued throughout the year to ensure that members are well fed after each meeting; they are indeed the mainstay of the Society! Last, but certainly not least, the Society owes an enormous debt of gratitude to Fr Alexander Nadson. Not only does he make a great contribution to the academic life of the Society, but, as Rector of the Byelorussian Catholic Mission in London, provides the facilities which are necessary for the Society to be able to hold its meetings.

Owing to pressure of work the Hon. Secretary, Dr Shirin Akiner, was compelled to resign. I should like to thank her for her services to the Society, and to thank my colleague Dr Lindsey Hughes for assuming the secretarial mantle at such short notice.

14 July 1983

JAMES DINGLEY

Hon. Chairman 


\section{The Chairman's Annual Report for the Year 1983-84}

During the academic year 1983-84 the Society organized the eighteenth annual course of lectures on Byelorussian history, literature and culture. The following lectures were included in the course:

10 November 'Catholic trends in early 20th-century Byelorussian poetry', Very Revd A. Nadson

12 January 'Lavrentij Zizanij's Lexis (Vilna, 1596); a milestone in East Slavonic lexicography', Dr H. Leeming

2 February 'Byelorussian Landscapes in the fiction of Tadeusz Konwicki', Ms N. Taylor

8 March 'The History of the Jews in Vilna', Prof. C. Abramsky

10 May 'M.A. Savicki: the making of a People's Artist of the USSR', Dr L. Hughes

21 June 30 years of the Anglo-Byelorussian Society: towards a history of Byelorussians in Great Britain'. A celebration.

Attendances at the lectures ranged from 20 to 38. It was an especial pleasure to welcome Professor Abramsky on his first visit to the Society. The celebration of the Society's 30th anniversary was well attended by members and friends. (It should be noted that the celebration received publicity in The Times Higher Educational Supplement of 1.6.84). On that day we were keenly aware of the debt owed by the Society to Bishop Sipovich and Auberon Herbert; much has been achieved during the thirty years of the Society's existence, but before we congratulate ourselves too much, let us ensure that we - all members and friends of the Society - do what we can to ensure that it will continue to exist.

The academic year was also marked by other events in which the Society was involved. Without doubt the most important of these was the one-day international seminar held on 15 October 1983 to mark the centenary of the birth of Vacłaŭ Lastoŭski. The following papers were read at the seminar;

Prof. A. Adamovič (New York): 'The Herald of the Byelorussian Renaissance (Łastoŭski and Byelorussian literature)'

Dr A. Barščeŭski (Warsaw): 'Łastoŭski's Karotkaja historyja Biełarusi as an attempt to define Byelorussian national identity'

Prof. dr hab. A. Bartoszewicz (Warsaw): 'Łastoŭski as bibliographer (with special reference to his Historyja biełaruskaj (kryŭskaj) knihi)' 
Mr J. Dingley (Reading and SSEES): 'Łastoŭski and political events of 1917-23'

Dr V. Sienkievič (Palamos) : 'Łastoŭski's historical concepts'

Mr A. Šukielojc (New York) : 'Łastoǔski as ethnographer'

Three of these papers are included in the present issue of the Journal of Byelorussian Studies.

The seminar was organized jointly with the Francis Skaryna Byelorussian Library and the Association of Byelorussians in Great Britain. The organizers of the seminar would like to record their gratitude to the British Universities Association of Slavists and the British National Association of Soviet and East European Studies for their allocation of generous financial support from the Ford Foundation grant.

On 12 September 1984 Dr A. Barszczewski and Dr Z. Skibińska of the Byelorussian Department of Warsaw University held an informal seminar in the Francis Skaryna Library.

During the year the Society published a book entitled Miniatures, a bilingual selection of short prose pieces by Sokrat Janovič, with the Byelorussian text and parallel English translation by Shirin Akiner. Dr Akiner has performed a valuable service to Byelorussian literature by bringing an interesting writer to the attention of a wider public. Publication of the book was made possible by a grant from the Byelorussian Charitable Trust.

I am happy to welcome two new members to the Society: Mr A. Laszuk (proposed by $\mathrm{Mr}$ J. Michaluk and seconded by myself) and $\mathrm{Mr}$ A. Rozaniec (proposed by myself and seconded by Dr L. Hughes).

The Council of the society met once during the year, on 14 June 1984. It was agreed to recommend to the Annual General Meeting the the Most Revd. Vladimir L. Tarasevitch OSB, Titular Bishop of Mariamme and Apostolic Visitator for the Byelorussian Faithful outside Byelorussia, be invited to become a vice-president of the Society. I had already written to him, offering the congratulations and best wishes of members of the Society on his appointment as Bishop. The Council also decided to examine ways of honouring the memory of Auberon Herbert, perhaps in the form of a framed scroll.

I sent a letter of condolence in the name of the Society to Dame Katherine Macmillan on the death of her husband, Maurice Macmillan. Mrs Asipowich represented the Society at the funeral, at which Mgr Nadson had been invited to say a blessing.

I am very grateful to all members of the Council for their active support in the running of the Society. The Secretary (Dr L. Hughes) ensures that there actually will be a lecture course, and the Treasurer (Mr P. Asipowich) has once again safely ensured that we have a positive balance in the bank. The Society owes thanks to the Byelorussian Charitable Trust for its continued invaluable support. We are all grateful to Dr P. Mayo for producing another issue of the Journal of Byelorussian Studies, and for actively seeking new contributions for further issues. I should like to thank Mgr Nadson and the Byelorussian Catho- 
lic Mission on behalf of the Society for permission to use the room where we hold our meetings, and Mrs Michaluk and Mrs Dziejko for ensuring that the lectures are followed by opportunities to enjoy good food and drink. Finally I should like to extend my thanks to all members and friends of the Society for making the past year such a successful one.

The 1984-85 lecture series is already under way. Planning is well advanced for a two-day international seminar entitled 'Francis Skaryna and the Renaissance in Byelorussia' to be held on 28-29 September 1985 in the Francis Skaryna Library. Full details will be issued later.

1 November 1984

JAMES DINGLEY

Hon. Chairman 